\title{
Nuclear power's litmus test
}

\begin{abstract}
A crucial test of public confidence in nuclear power will take place in six states during next month's Presidential election. Colin Norman reports from Washington.
\end{abstract}

WHEN residents of Arizona, Colorado, Montana, Ohio, Oregon and Washington mark their ballot papers on November 2, they will do more than cast votes for candidates for sundry political offices. They will also vote on resolutions which would place strictsome say crippling-controls on nuclear power plants in their states.

The resolutions are stirring up considerable debate, and large sums of money are being spent both to promote and defeat them. Although the number of power plants affected is relatively small compared with the total number planned for the United States, the votes are regarded as a litmus test of public attitudes towards nuclear power. With the election less than a month away, opinion polls indicate that the resolutions stand a good chance of being approved in at least two statesColorado and Oregon.

Although there are some differences between the resolutions on the ballots in the six states, they would all set three important conditions on the operation of nuclear power plants.

- There must be no limit to the total amount of damages which could be claimed by victims of a nuclear accident. At present, a federal law, the Price-Anderson Act, limits the nuclear industry's liability to a total of $\$ 560$ million for each accident.

- Before new power plants could be operated, the state legislature would have to be convinced that major safety systems-including the much-discussed emergency core cooling system-would operate properly in an emergency. Approval would require a two-thirds vote in the legislature.

- Similarly, at least two thirds of the legislature would have to be satisfied that adequate, proven technologies exist for transport, storage, and disposal of radioactive wastes.

At present, it is doubtful that the nuclear industry could meet those conditions. Thus, passage of the resolution in any state would virtually rule out nuclear expansion in that state.

Voters in California were presented with a similar choice last June, when a nuclear safety proposition was placed on the ballot papers in the Presidential primary elections. That proposition, which would have imposed the same three conditions on nuclear plants in
California, was eventually defeated.

Supporters of the resolution in Oregon and Colorado, and to some extent in the other four states, expect to fare better, however. For one thing, the steam was taken out of the California campaign at the last moment when the state legislature passed a package of nuclear safety bills which included some of the proposition's requirements. But, more important, the California proposition would have applied to existing, as well as planned, power plants. The Oregon and Colorado measures, by contrast, would specifically exempt existing plants.

A potentially important factor in the vote on the Oregon resolution is that during the Oregon primary election earlier this year, Jimmy Carter, the Democratic Presidential candidate, virtually endorsed the resolution. He said that although he would not try to advise people how to vote on the matter, if he were an Oregonian, he would support the resolution. He did not endorse the California proposition, however, largely because it would have applied to existing plants.

Supporters of the resolution also like to point out that both Colorado and Oregon have approved a number of environmental laws long before other states. Oregon, for example, was the first state to outlaw the sale of plastic bottles and aerosol sprays containing fluorocarbons, and among Colorado's environmental achievements is the passage of a resolution which stopped the Winter Olympics being held there.

But the most solid piece of evidence that the nuclear industry is in trouble in Colorado and Oregon comes from public opinion polls published early in October in newspapers in Denver and Portland. They suggested that public sympathy was then running nearly two to one in favour of the resolutions. Although that margin is sure to close as the election draws near industry officials say they are very concerned.

Thus, if the resolutions are adopted by any state this November, it would give the anti-nuclear movement a boost in future efforts. But, by the same token, if the resolutions are defeated, the nuclear industry could claim a vote of confidence. Clearly, the stakes are high.

\section{GAO knocks ERDA}

Although the Energy Research and Development Administration (ERDA) is responsible for developing nuclear energy technologies in the United States, ERDA officials insist that they have not tried to influence the outcome of the referenda on nuclear safety being held in various states. Those assertions are, however, called into question by a report published last week by the General Aiccounting Office (GAO), an investigative agency of the US Congress.

According to the report, between February and April 1976-when debate on the California referendum was raging-ERDA distributed 78,600 copies of a pro-nuclear pamphlet in California. According to GAO, the pamphlet "was not objective, is propaganda, and was not a proper document for release to the public". The pamphlet was used by the nuclear industry in California in their campaign to defeat the California proposition.

ERDA officials have claimed that the document-a series of so-called myths and facts about nuclear power $\longrightarrow$ was prepared solely for internal distribution within the agency. It was intended, they have argued, for employees in the controversial liquid metal fast breeder reactor pro- gramme, to help answer criticisms of the programme and to lift morale.

GAO found such assertions hard to swallow, however, since the fast breeder programme employs only about 6,700 people, yet 100,000 copies of the pamphlet were printed. Moreover, GAO found it difficult to understand why the bulk of the copies were sent to California, while most of the breeder reactor work is going on in other states.

Nevertheless, GAO stopped short of actually accusing ERDA officials of trying to influence the California vote-in fact, it specifically states that it could find no such evidence and suggested that ERDA officials had not actually violated any laws. The report did not attempt to explain why so many copies of the pamphlet were distributed in Califfornia at that particular moment, however.

As for the quality of the pamphlet, the GAO report suggested that it was so superficial and misleading that it was not even suitable for distribution to ERDA employees as part of morale lifting effort. "ERDA should not place itself in the position of misleading others-whether it be the public or its own or contractor employeesfor the sake of raising morale", the report argued. 